\title{
Profile Of Children With Guillan Barre Syndrome In RSUP Haji Adam Malik Medan: Events In 5 Years
}

Febi Putri Lestari $\mathrm{H}^{\mathrm{a}}$, Yazid Dimyati ${ }^{\mathrm{b}}$, Beby Syofiani Hasibuan ${ }^{\mathrm{c}}$

Department of Child Health, Faculty of Medicine University of Sumatra Utara, Medan,Indonesia

a febihutasuhut@gmail.com

${ }^{a}$ Pediatric Resident, Child Health Departement, Faculty of Medicine,University of North Sumatra, Medan,Indonesia bNeurology Pediatric Consultant, Child Health Departement, Faculty of Medicine,University of North Sumatra, Medan-Indonesia 'Perinatology Pediatric Consultant, Child Health Departement, Faculty of Medicine,University of North Sumatra, Medan-Indonesia

\begin{abstract}
Background : Guillain-Barré syndrome (GBS) is an acute demyelinating disease of the peripheral nervous system characterized clinically by flaccid paralysis. The mortality rate in children is about $3-5 \%$. Early diagnosis and therapy important for patient's prognosis.

Objective : The aim of this study was to acquaint the profile of children with Guillain-Barré syndrome at the RSUP HAM Medan Hospital from 2016 to 2020.

Methods : This study is a descriptive study with a retrospective design. The population and sample with total sampling of the children with GBS diagnosed at the HAM Medan Hospital recorded in the medical record from January 2016 to December 2020. The data were analyzed univariately and presented with a frequency distribution.

Results: From this study, 41 children with GBS were found. There were 18 children (43.9\%) with age between 10-14 year (female was 22 people (53.7\%). Based on the Brighton Criteria for GBS children, most of the children was on level 2 that were 35 people $(85,4 \%)$. From the results of the EMG (Electromyography) examination in GBS children, 24 people $(58.5 \%)$. had the most types of GBS were Acute Motor Axonal Neuropathy (AMAN). There was no cytoalbumin dissociation was found on CSF analysis. Mostly 28 people had supportive therapy, that was the most used type of therapy. The disability scale shows that children who can walk with the help of a cane or supporting equipment (disability scale 3 ) was 26 people (63.4\%). Based on the length of stay in the hospital, 26 children (63.4\%) were treated for 8-14 days.

Conclusion: Majority the case of GBS in the RSUP HAM Medan was similar previous studies. Our results can be used as baseline data for understanding the characteristics of GBS in Indonesia.
\end{abstract}

Key word: Guillain-Barré syndrome; profile; children.

\section{Introduction}

Guillain-Barré syndrome (GBS) is an acute demyelinating disease of the peripheral nervous system characterized clinically by acute flaccid paralysis and is one of the leading causes of neuromuscular paralysis worldwide. ${ }^{1}$ The incidence of GBS occurs in only 1 or 2 cases per 100,000 worldwide each year. ${ }^{2,3}$ From 1996 to 2012, the Canadian Pediatric Surveillance Program (CPSP) received 773 case reports of Acute Flaccid Paralysis (AFP), an estimated annual incidence of 0.4-1.1 per 100,000 children, of whom 69\% were diagnosed as GBS. ${ }^{4}$ The incidence of GBS based on population-based studies is estimated to be $0.5-1.5$ cases per 100,000 children under 16 years of age. ${ }^{5}$ Data from Cipto Mangunkusumo Hospital (RSCM) Jakarta showed that at the end of 2010-2011 there were 48 cases of GBS in one year with various number of cases per month. ${ }^{6}$

Guillain-Barré syndrome is a life-threatening disease that can cause both morbidity and mortality even with medical treatment. The mortality rate in children is about $3-5 \% .^{7}$ Respiratory insufficiency can 
occur in patients with GBS and can lead to death in these patients. ${ }^{1,8}$ Early diagnosis of GBS affects the patient's prognosis. ${ }^{9}$ The Brighton Collaboration created the Brighton criteria, a novel set of case definitions for GBS that can estimate the level of diagnostic certainty based on clinical examination, cerebrospinal fluid examination, and neurophysiological examination findings. ${ }^{8,10}$

GBS in children has a good prognosis, especially if intravenous immunoglobulin (IVIG) was given as soon as the clinical suspicion is established. According to research by Salehiomran MR et al, only one out of 17 children with GBS suffered from respiratory paralysis. Sixteen other patients showed complete recovery, while one patient with respiratory paralysis required a wheelchair. ${ }^{5}$ In 1978 , Hughes et al. proposed a disability scale that has been widely used until now. ${ }^{11}$

The purpose of this study was to determine the profile of children with Guillain-Barré syndrome at the HAM Hospital in Medan from 2016 to 2020.

\section{Methods}

This is a descriptive study to determine the profile of children with GBS. Researchers will use medical record data from the Haji Adam Malik Provincial General Hospital (RSUP HAM) Medan to identify all research subjects having a diagnosis of Guillain-Barré syndrome in pediatric patients from 2016 to 2020. Age, gender, Brighton Criteria Level, GBS Type, treatment, GBS Disability Scale, Length of Stay, and CSF Analysis Characteristics are among the data collected. Table 1 shows the Brighton criterion level.

\section{Table 1. Guillain-Barré syndrome based on Brighton criteria ${ }^{26}$}

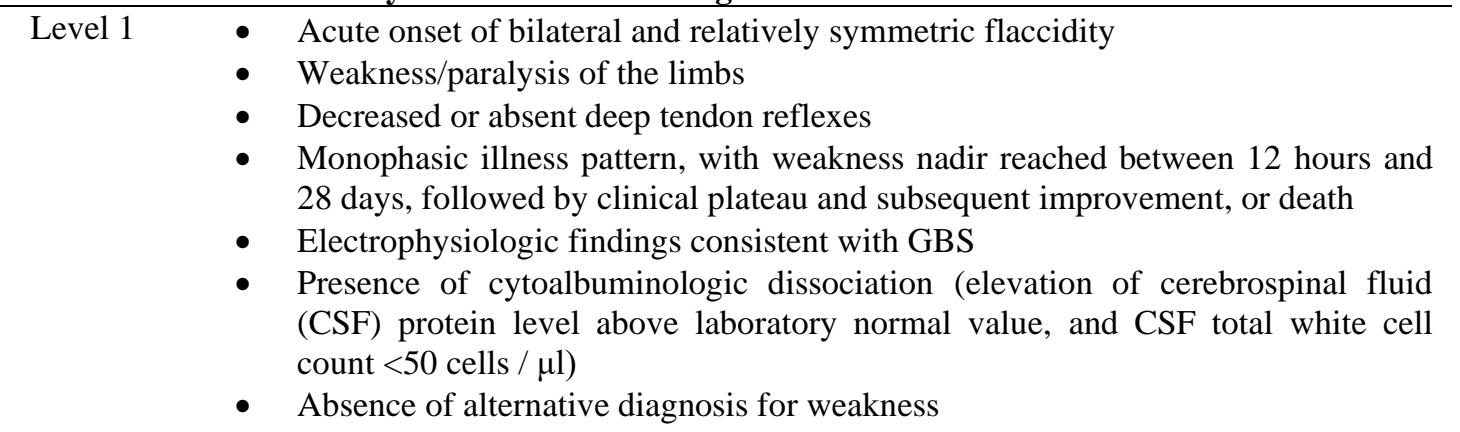

Level 2 - Acute onset of bilateral and relatively symmetric flaccidity

- Weakness/paralysis of the limbs

- Decreased or absent deep tendon reflexes

- Monophasic illness pattern, with weakness nadir reached between 12 hours and 28 days, followed by clinical plateau and subsequent improvement, or death

- Cerebrospinal fluid (CSF) with a total white cell count $<50$ cells / mm3 (with or without CSF protein elevation above laboratory normal value) 
- If CSF not collected or results not available, electrodiagnostic studies consistent with GBS

Level 3 - Acute onset of bilateral and relatively symmetric flaccidity

- Weakness/paralysis of the limbs

- Decreased or absent deep tendon reflexes at least in affected limbs

- Monophasic illness pattern, with weakness nadir reached between 12 hours and 28 days, followed by clinical plateau and subsequent improvement, or death

Level 4

- Absence of alternative diagnosis for weakness

- More than one criteria of:

- Acute onset of bilateral and relatively symmetric flaccidity

- Weakness/paralysis of the limbs

- Decreased or absent deep tendon reflexes at least in affected limbs

- Absence of alternative diagnosis for weakness

This study has been approved by the Health Research Ethics Committee, Faculty of Medicine, University of North Sumatra number. Univariate analysis used SPSS version 20.0 by displaying the size of frequency distribution and percentage.

\section{Study Results}

This study included 41 children with Guillain-Barré syndrome who were hospitalized at the HAM Hospital in

Medan from January 2016 to December 2020. Table 2 lists the characteristics of the research sample.

Table 2. Age, Gender, GBS Type, Treatment, and Length of Stay Distribution in Children with Guillain-Barré at H. Adam Malik Hospital Medan

\begin{tabular}{lcc}
\hline Demography Characteristics & Frequency & \% \\
\hline Age & 6 & 14.6 \\
$0-4$ years old & 14 & 34.1 \\
$5-9$ years old & 18 & 43.9 \\
$10-14$ years old & 3 & 7.3 \\
15-18 years old & 19 & 46.3 \\
Gender & 22 & 53.7 \\
Male & & 22 \\
Female & 9 & 19.5 \\
GBS Type & 8 & 58.5 \\
AIDP & 24 & 31.7 \\
AMSAN & & 68.3 \\
AMAN & 13 & \\
Treatment & 28 & \\
Intravenous Immunoglobulin & & \\
Supportive & & \\
Length of stay & &
\end{tabular}




\begin{tabular}{lcc}
\hline 1-7 days & 8 & 19.5 \\
8-14 days & 26 & 63.4 \\
$>14$ days & 7 & 17.1 \\
\hline
\end{tabular}

Based on Brighton criteria for GBS in children (Table 3), mostly subjects (82.9\%) were at level 2, while the rest were at level $1(17.1 \%)$.

Table 3. Frequency Distribution of Brighton Criteria Level in Children with Guillain-Barré Syndrome at H. Adam Malik Hospital Medan

\begin{tabular}{lcc}
\hline Brighton Criteria & Frequency & $\%$ \\
\hline Level 1 & 7 & 17.1 \\
Level 2 & 34 & 82.9 \\
\hline Total & 41 & 100 \\
\hline
\end{tabular}

Disability scale in children with GBS. Table 4 shows that most of the children had disability scale $3(63.4 \%)$ and the least were disability scale 2 and $5(4.9 \%)$.

Table 4. Frequency Distribution of Disability Scale in Children with Guillain-Barré Syndrome at $\mathbf{H}$. Adam Malik Hospital Medan

\begin{tabular}{lcc}
\hline Disability Scale & Frequency & \% \\
\hline Can walk without the help of cane, but cannot do manual work & 2 & 4.9 \\
Can walk with the help of cane or supportive equipment & 26 & 63.4 \\
Limited activity in bed/chair & 11 & 26.8 \\
Need mechanical ventilation & 2 & 4.9 \\
\hline Total & $\mathbf{4 1}$ & $\mathbf{1 0 0}$ \\
\hline
\end{tabular}

Lumbar puncture was only performed on 7 children (17.1\%), while 34 children (82.9\%) did not have one. Lumbar puncture results of the 7 children with GBS (Table 5) showed that there was no increase in protein $(>45 \mathrm{mg} / \mathrm{dL})(100 \%)$ in, however there was an increase in leukocyte count in 5 children $(71.4$ percent $)$. There was no cytoalbumin dissociation.

Table 5. Lumbar Puncture Fluid Examination Results

\begin{tabular}{lccc}
\hline Laboratory Results & $\mathbf{n}(\%)$ & Average (SD) & Median (Min - Max) \\
\hline $\begin{array}{l}\text { LDH, U/L } \\
\quad<200 \mathrm{U} / \mathrm{L}\end{array}$ & $7(100)$ & $29.86(4.34)$ & $30(22-37)$ \\
$\begin{array}{l}\text { Total Protein, mg/dL } \\
\quad \leq 45 \mathrm{mg} / \mathrm{dL}\end{array}$ & $7(100)$ & $16.11(8.71)$ & $16(0.8-28)$ \\
$\quad \begin{array}{l}\text { Leukocyte Count } \\
\quad \geq 0.003\end{array}$ & $5(71.4)$ & $0.06(0.11)$ & $0.005(0.001-0.284)$ \\
$\quad<0.003$ & $2(28.6)$ & & \\
$\quad$ Erythrocyte Count & & $0.0001(0.0004)$ & $0(0-0.001)$ \\
\hline
\end{tabular}




\begin{tabular}{lccc}
+ & $1(14.3)$ & & \\
- & $6(85.7)$ & $76.43(28.98)$ & $64(47-119)$ \\
Glucose, mg/dL & & & \\
$\quad$ Normal (40-76) & $5(71.4)$ & & $8(8-9)$ \\
$\quad$ Increased (>76) & $2(28.6)$ & & \\
$\mathrm{pH}$ & & & \\
$7-8$ & $5(71.4)$ & & $97.7(20.8-10)$ \\
$>8$ & $2(28.6)$ & & $2.3(0-79.2)$ \\
MN Cells & & $79.74(33.36)$ & \\
PMN Cells & & $20.26(33.36)$ & \\
\hline
\end{tabular}

\section{Discussion}

The initial characteristic data in this study showed that the proportion of female gender (53.7\%) was higher than male (46.3\%). According to a study by Mahmoud et al. in 2019, there was no difference in the proportion of male and female sex. ${ }^{12}$ Several investigations on the characteristics of children with GBS, however, revealed that male outnumbered females (54-58\%: 46-42\%). ${ }^{13-18}$ The patients in this study were predominantly 10-14 years old (43.9\%); study by Levinson in Denmark and Sandip in India both found the same result. GBS was most commonly diagnosed in children under the age of ten years old. The average length of stay for children with GBS was 14 days in studies conducted in Bangladesh and Turkey. ${ }^{15,16}$ In this study, the longest length of stay was 8-14 days. One study from the United States reported shorter hospitalizations (5-13 days, median: 7 days). ${ }^{19}$ Study from Oman, on the other hand, showed longer hospital stays (range: 5-116 days, median: 20.4 days). ${ }^{20}$ The difference in length of stay is mainly due to differences in the treatment obtained, where in developed countries such as the United States, treatment for children with GBS is in accordance with the recommendations for managing GBS in children.

In this study, the frequencies of AMAN, AIDP and AMSAN were 58.5\%, 22\%, and 19.5\%, respectively. This is similar to studies published from China, Spain, India, Malaysia, Japan, Mexico, and Bangladesh, where the axonal type is more common than the demyelinating type. ${ }^{16-18,22}$ In a study of 108 children with GBS conducted in India by Sandip et al, AIDP was seen in $52.8 \%(\mathrm{n}=57)$, the axonal pattern in $33.3 \%(\mathrm{n}=36)$, and a normal EMG pattern in $5.6 \%(\mathrm{n}=6) .{ }^{23} \mathrm{~A}$ study in India found that children with GBS with axonal variation had higher Hughes disability scores at presentation, at the peak of illness, at discharge and at follow-up at eight weeks and six months. ${ }^{23}$ The axonal type has a higher incidence rates of gastrointestinal symptoms, while upper respiratory tract disease was more common in AIDP according to some studies. ${ }^{24,25,26}$ Several studies showed that axonal variants are associated with higher ventilation requirements. Other investigations reported no significant changes in axonal type or demyelination on the frequency of respiratory support device use or the outcome of children with GBS. ${ }^{17,27,28}$ 
Treatment with intravenous immunoglobulin $(0.4 \mathrm{~g} / \mathrm{kg}$ for 5 days $)$ and plasmapheresis (typically five sessions at 200-250 ml/kg) has been shown to be effective for GBS. ${ }^{4,11,30,31}$ In general, IVIG is considered the first choice of treatment because it is easy to administer, widely available and associated with less side effects compared to plasmapheresis. ${ }^{30,32}$ However, plasmapheresis is less expensive than IVIG and could theoretically be the preferred treatment option in low-income countries..$^{34,35,36}$ The lack of national treatment guidelines and the high costs of existing treatment contribute to poorer prognostic outcomes and higher GBS mortality rates in low-income countries compared to high-income countries. ${ }^{37}$

Cytoalbumin dissociation is one of the validated diagnostic criteria for GBS, reflecting impaired blood-CSF barrier due to neuroinflammation. However, inflammation in GBS varied between patients and elevated protein levels were not found in all cases. ${ }^{38}$ The percentage of cytoalbumin dissociation was shown to vary between 44 and $81 \%$ depending on lumbar puncture (LP) time, with a lower rate early in the disease course (sensitivity 50\% during the first week). ${ }^{10,39}$ Furthermore, protein levels in CSF have been demonstrated to be age dependent, and when age-adjusted values are utilized, the sensitivity of total protein (TP) for diagnosing albuminocytologic dissociation decreases. ${ }^{38,39}$ Based on the data collected in this study (Table 5), lumbar puncture was only performed on 7 children $(17.1 \%)$. This is because there are some subjects that refused the procedure.

The Brighton criteria are the criteria used to diagnose children with GBS according to the modalities available at the health center in the area. Brighton criteria are divided into 4 levels of diagnostic certainty. In this study, the majority of the subjects were at level $2(85.4 \%)$, where at this level only one examination was carried out, namely nerve conduction study (NCS) and lumbar puncture. For level 1, only 14.6\% were found. This is because the subject's family mostly does not approve of the lumbar puncture, and only relies on one modality, the nerve conduction study. In a study aimed at validating the Brighton criteria for diagnosing GBS in Pakistan, it was concluded that the Brighton criteria for the diagnosis of GBS could be used with acceptable sensitivity for level 3 certainty (does not require clinical laboratory testing), level 2 certainty (using CSF examination or NCS), and level 1 certainty (using both tests). ${ }^{40}$

The completeness of the data about the primary diagnostic characteristics is required for the classification of GBS using the Brighton criteria. As a result, the criteria were validated independently for each patient subgroup using the entire data set as well as the entire patient cohort. ${ }^{41}$ Neuroelectrophysiological examination and CSF examination were positively correlated with the diagnostic certainty level of the Brighton criteria $(\mathrm{P}<0.01) .{ }^{21}$ When the Brighton criteria and the National Institute of Neurological Disorders and Stroke (NINDS) were compared in a cohort analysis, a diagnostic certainty of at least Level 3 of the Brighton criteria (95 percent) exhibited a sensitivity comparable to the NINDS criteria. ${ }^{22}$ 
The sensitivity of the Brighton criteria in the GBS patient population has been studied in numerous research. Sensitivity ranged from $60 \%$ to $98 \%$ in different groups. ${ }^{9,10,41,42}$ In the Malaysian study by Chen et al regarding the validity of the Brighton criteria in GBS patients, the highest level of diagnostic certainty (Level 1) was achieved in $67 \%$ of patients, followed by $25 \%$ at Level 2, $4 \%$ at Level 3 and $5 \%$ at Level $4 .{ }^{21}$ The findings in Malaysia are comparable to studies from the Netherlands where Level 1 diagnostic certainty was achieved in $61 \%$ of their adult GBS population. ${ }^{10,21}$ High diagnostic rates have been reported in GBS cohorts in Bangladesh and China, where level 1 was achieved in $91 \%$ and $79 \%$ of patients, respectively. ${ }^{42,43}$ There are several reasons for this difference. The interval from GBS onset to CSF examination was longer in both countries (Bangladesh: median 11 days; China: mean 13 days) compared to the Malaysian cohort (median 8 days). This results in a higher probability of obtaining CSF albuminocytological dissociation patterns..$^{22,42,44}$

Jafari et al. conducted research on 79 children with GBS aged 4 to 14 years in India using the Brighton criteria. According to the study, children with GBS usually met the Brighton level 3 criteria (86\%) without any CSF or NCS studies. In this investigation, there was no difference in sensitivity between levels 2 and $3(84 \%$ vs $86 \%, \mathrm{p}>0.05) .{ }^{45}$ Although most of the cases met the level 3 criteria, 11 cases failed to meet the level 3 criteria due to lack of data and documentation. Level 1 criteria were found in $62 \%$ of patients. In that cohort study, 17 individuals (22\%) met the level 2 criteria after CSF analysis revealed no cytoalbumin dissociation in the second week after acute flaccid paralysis (AFP). The study concluded that the Brighton criteria could be used in low-income countries with moderate to high sensitivity. ${ }^{45}$

\section{Conclusion}

According to studies on children with GBS from 2016 to 2020, the majority are females between the ages of 10 and 14, with an average stay of 8 to 14 days. Axonal type (AMAN) was the most common, followed by demyelinating type (AIDP), with 31.7 percent receiving intravenous immunoglobulin treatment. Based on Brighton criteria, majority of children were diagnosed with a diagnostic level 2 and the majority of children on a disability scale with disability scale 3 were able to walk with the assistance of a cane or supportive equipment.

\section{REFERENCES}

1. Marcdante KJ, Kliegman RM, Jenson HB BR. Guillain Barre' Syndome. Kliegman RM, Editor. Nelson Textbook of Pediatrics. Ed. 20. Stanton BF: Elsevier; 2016; 3010-13.

2. Kementerian Kesehatan Republik Indonesia. Guillain Barre' Sindrom. 2011. Download from http://www.depkes.go.id/article/print/1628/guillain-barre-sindrom.html. Accessed in 2 Januari 2021.

3. Zaeem Z, Siddiqi ZA, Zochodne DW. Autonomic involvement in Guillain-Barré syndrome: an update. Clin Auton Res. 2018; 4: 1-11. 
4. Van PA, Ruts L, Jacobs BC. Clinical features, pathogenesis, and treatment of Guillain-Barré syndrome. Lancet Neurology. 2008 7: 939-50.

5. Top KA, Desai S, Moore D. Guillain-Barre' Syndrome After Immunization in Canadian Children (1996-2012). The Pediatric Infectious Disease Journal. 2015; 34: 1411-13.

6. Japardi I. Sindrom Guillain-Barre. Medan. Fakultas Kedokteran Universitas Sumatera Utara. 2002. Download from http://library.usu.ac.id/download/fk/bedah-iskandar\%20japardi46.pdf. Accesed in 2 Januari 2021

7. Sladky JT, Ashwal S. Inflammatory neuropathies. Swaiman KF, Ashwal S, Ferreiro DM, Schor NF, penyunting. Swaiman's pediatric neurology. $6^{\text {th }}$ edition. Edinburgh: Elsevier-saunders; 2017; 1532-48.

8. Salehiomran MR, Nikkhah A, Mahdavi M. Prognosis of Guillain-Barré syndrome in children. Iran J Child Neurol. 2016;10(2):38-41.

9. Boostani R, Farveh R, Morteza S, Mina K. A A follow-up study on Guillain- Barre' syndrome and validation of Brighton criteria. Iranian Journal of Neurology. 2019;18(2):64-9.

10. Fokke C, vanden BB, Drenthen J. Diagnosis of Guillain-Barre's syndrome and validation of Brighton Criteria. BRAIN A Journal of Neurology. 2014; 137: 33-43.

11. Hughes RA, Newsom-Davis JM, Perkin GD, Pierce JM. Controlled trial prednisolone in acute polyneuropathy. Lancet 1978; 2(8093): 750-3

12. Ashrafi MR, Mohammadalipoor A, Naeini AR. Clinical Characteristics and Electrodiagnostic Features of Guillain-Barré Syndrome Among the Pediatric Population. JChild Neurol. 2020;35(7):448-455.

13. Levison LS, Thomsen RW, Markvardsen LK, Christensen DH, Sindrup SH, Andersen H. Pediatric Guillain-Barré Syndrome in a 30-Year Nationwide Cohort. Pediatr Neurol. 2020; 107:57-63.

14. Konuşkan B, Okuyaz Ç, Taşdelen B, Kurul SH, Anlar B. Turkish Childhood Guillan-Barre Syndrome Study Group. Electrophysiological Subtypes and Prognostic Factors of Childhood Guillain-Barré Syndrome. Noro Psikiyatr Ars. 2018;55(3):199-204.

15. Luo HY, Li XJ, Cheng M. Clinical characteristics of children with Guillain-Barré syndrome and factors associated with disease severity. J Clin Neurosci. 2021;92:120-125.

16. Sedano MJ, Orizaola P, Gallardo E. A unicenter, prospective study of Guillain-Barré syndrome in Spain. Acta Neurol Scand. 2019;139(6):546-554.

17. Singh S, Gupta N, Gupta AM, Chandel AS, Waghela S, Saple P. Clinical profile and predictors for outcome in children presenting with Guillain-Barré syndrome. J Family Med Prim Care. 2020;9(10):5316-5319.

18. Liang JF, Sun RD, Wang RX, Luo J, Wang HD, Jiang J. Clinical features of children with GuillainBarré syndrome and the significance of Brighton criteria. Zhongguo Dang Dai Er Ke Za Zhi. 2021;23(2):153-157.

19. Koul RL, Alfutaisi A. Prospective study of children with Guillain-Barré syndrome. Indian J Pediatr .2008;75:787-790.

20. Bourque PR, Brooks J, Warman J, Breiner A. Cerebrospinal fluid total protein in Guillain-Barré syndrome variants: correlations with clinical category, severity, and electrophysiology. J Neurol. 2020;267(3):746-751.

21. Tan CY, Razali SNO, Goh KJ, Shahrizaila N. Diagnosis of Guillain-Barré syndrome and validation of the Brighton criteria in Malaysia. J Peripher Nerv Syst. 2020;25(3):256-264.

22. Choe YJ, Cho H, Bae GR, Lee JK. Guillain-Barré syndrome following receipt of influenza A (H1N1) 2009 monovalent vaccine in Korea with an emphasis on Brighton Collaboration case definition. Vaccine.2011;29:2066-2070. 
23. Liu S, Xiao Z, Lou M. Guillain-Barré syndrome in southern China: Retrospective analysis of hospitalised patients from 14 provinces in the area south of the Huaihe River. J Neurol Neurosurg Psychiatry. 2018;89:618-26.

24. Kannan MA, Ch RK, Jabeen S A, Mridula K R, Rao P, Borgohain R. Clinical, electrophysiological subtypes and antiganglioside antibodies in childhood Guillain-Barré syndrome. Neurol India. 2011;59:727-32.

25. Sankhyan N, Sharma S, Konanki R, Gulati S. Childhood Guillain-Barré syndrome subtypes in northern India. J Clin Neurosci. 2014;21:427-30.

26. Nagasawa K, Kuwabara S, Misawa S, Fujii K, Tanabe Y, Yuki N, et al. Electrophysiological subtypes and prognosis of childhood Guillain-Barré syndrome in Japan. Muscle Nerve 2006;33:766-70.

27. Konuşkan B, Okuyaz Ç, Taşdelen B, Kurul SH, Anlar. Electrophysiological Subtypes and Prognostic Factors of Childhood Guillain-Barré Syndrome. Noro Psikiyatr Ars. 2018;55(3):199-204.

28. Khan F, Ng L, Amatya B, Brand C, Turner L. Multidisciplinary care for Guillain- Barré syndrome. Eur. J. Phys. Rehabi Med. 2011; 607-61.

29. Korinthenberg, R., Schessl, J. \& Kirschner, J. Clinical presentation and course of childhood GuillainBarré syndrome: a prospective multicentre study. Neuropediatrics. 2017;(38), 10-17.

30. Hughes RAC, Swan AV, van Doom PA. Intravenous immunoglobulin for Guillain-Barre syndrome. Cochrane Database of Systematic Review. 2014;9.

31. Rapahel JC, Chevret S, Hughes RAC, Annane D. Plasma exchange for Guillain-Barre syndrome. Cochrane Database of Systematic Review.2012;7.

32. Chaudhuri JR. Clinical outcome of Guillain- Barré syndrome with various treatment methods and cost effectiveness: a study from tertiary care centerin South India: Yashoda GBS registry. Neurol Asia. 2014; (19):263-270.

33. Willison HJ, Jacobs BC, van Doorn PA. Guillain-Barré syndrome: surveillance and cost of treatment strategies. Lancet. 2017;(389):253-254.

34. Kishore CK. Management of Guillain-Barré syndrome with plasmapheresis or immunoglobulin: our experience from a tertiary care institute in South India. Ren Fail. 2014 (36):732-736.

35. Islam B. Small volume plasma exchange for Guillain-Barré syndrome in resource-limited settings: a phase II safety and feasibility study. BMJ Open. 2018:8, e022862.

36. Papri N, Islam Z, Leonhard SE, Mohammad QD, Endtz HP, Jacobs BC. Guillain-Barré syndrome in low-income and middle-income countries: challenges and prospects. Nat Rev Neurol. 2021;17(5):285296.

37. Alshekhlee A, Hussain Z, Sultan B, Katirji B. Guillain-Barré syndrome: incidence and mortality rates in US hospitals. Neurology. 2018;70:1608- 1613.

38. Rath J, Zulehner G, Schober B. Cerebrospinal fluid analysis in Guillain-Barré syndrome: value of albumin quotients. J Neurol. 2021;268(9):3294-3300.

39. Alanazy MH, Bakry SS, Alqahtani A. Clinical features and outcome of Guillain-Barre syndrome in Saudi Arabia: a multicenter, retrospective study. BMC Neurol. 2021;21(1):275.

40. Bano S, Numan A, Siddique A. Validity of Brighton Criteria in the Diagnosis of Guillain-Barré Syndrome (GBS) in Pakistan. Pakistan Journal of Neurological Sciences. 2015; 8(10): 4-10.

41. Roodbol J, de Wit MCY, van DB. Diagnosis of Guillain-Barre syndrome in children and validation of the Brighton Criteria. Journal of Neurology. 2017; 264: 856-61.

42. Zeng Y, Liu Y, Xie Y, Liang J, Xiao Z, Lu Z. Clinical Features and the Validation of the Brighton Criteria in Guillain-Barré Syndrome: Retrospective Analysis of 72 Hospitalized Patients in Three Years. European Neurology.2019;1-8. 
43. Islam MB, Islam Z, Farzana KS, Sarker SK, Endtz HP, Mohammad QD, et al. Guillain-Barré syndrome in Bangladesh: validation of Brighton criteria. J Peripher Nerv Syst. 2016;21:345 - 351.

44. Sen S, Kumar A, Roy B. Clinical Outcome of Guillain-Barré Syndrome in 108 Children. Indian Pediatr. 2021;58(9):833-835.

45. Jafari H, Shinohara RT, Mateen FJ.Guillain-Barré Syndrome in India: Population-based validation of the Brighton criteria. Vaccine. 2011;29(52):9697-701. 